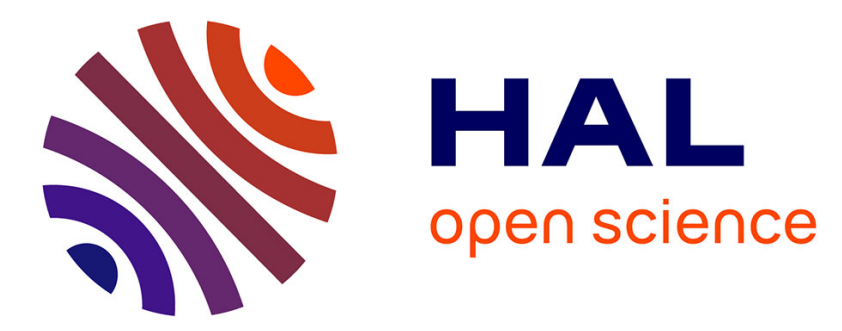

\title{
Modulation of $\mathrm{ER} \alpha$ transcriptional activity by the orphan nuclear receptor ERRß and evidence for differential effects of long- and short-form splice variants \\ Vincent Bombail, Frances Collins, Pamela Brown, Philippa T.K. Saunders
}

\section{- To cite this version:}

Vincent Bombail, Frances Collins, Pamela Brown, Philippa T.K. Saunders. Modulation of ER $\alpha$ transcriptional activity by the orphan nuclear receptor ERRß and evidence for differential effects of long- and short-form splice variants. Molecular and Cellular Endocrinology, 2009, 314 (1), pp.53. 10.1016/j.mce.2009.09.007 . hal-00529010

\author{
HAL Id: hal-00529010 \\ https://hal.science/hal-00529010
}

Submitted on 24 Oct 2010

HAL is a multi-disciplinary open access archive for the deposit and dissemination of scientific research documents, whether they are published or not. The documents may come from teaching and research institutions in France or abroad, or from public or private research centers.
L'archive ouverte pluridisciplinaire HAL, est destinée au dépôt et à la diffusion de documents scientifiques de niveau recherche, publiés ou non, émanant des établissements d'enseignement et de recherche français ou étrangers, des laboratoires publics ou privés. 


\section{Accepted Manuscript}

Title: Modulation of ER $\alpha$ transcriptional activity by the orphan nuclear receptor ERRß and evidence for differential effects of long- and short-form splice variants

Authors: Vincent Bombail, Frances Collins, Pamela Brown, Philippa T.K. Saunders

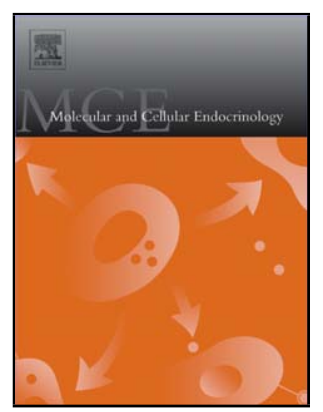

PII: S0303-7207(09)00490-0

DOI: doi:10.1016/j.mce.2009.09.007

Reference: MCE 7319

To appear in: $\quad$ Molecular and Cellular Endocrinology

Received date: 20-2-2009

Revised date: $\quad 31-7-2009$

Accepted date: $\quad$ 9-9-2009

Please cite this article as: Bombail, V., Collins, F., Brown, P., Saunders, P.T.K., Modulation of ER $\alpha$ transcriptional activity by the orphan nuclear receptor ERRß and evidence for differential effects of long- and short-form splice variants, Molecular and Cellular Endocrinology (2008), doi:10.1016/j.mce.2009.09.007

This is a PDF file of an unedited manuscript that has been accepted for publication. As a service to our customers we are providing this early version of the manuscript. The manuscript will undergo copyediting, typesetting, and review of the resulting proof before it is published in its final form. Please note that during the production process errors may be discovered which could affect the content, and all legal disclaimers that apply to the journal pertain. 
Modulation of ER $\alpha$ transcriptional activity by the orphan nuclear receptor ERRß and evidence for differential effects of long- and short-form splice variants.

Vincent Bombail, Frances Collins, Pamela Brown and Philippa TK Saunders.

5

MRC Human Reproductive Sciences Unit, Centre for Reproductive Biology, The Queen's

Medical Research Institute, 47 Little France Crescent, Edinburgh EH16 4TJ, Scotland

Short title: ERRß splice variants

10

Key words: oestrogen receptor, orphan receptor, F-domain, splice variant, ESRRB

Grant support: This work was supported by MRC HRSU Unit core funding to PTKS

(U.1276.00.002.00005.01).

15

\section{Corresponding Author:}

Professor Philippa TK Saunders

MRC Human Reproductive Sciences Unit,

Queen's Medical Research Institute,

2047 Little France Crescent,

Edinburgh EH16 4TJ

Telephone: +44(0)1312426388

p.saunders@ed.ac.uk 


\section{Abstract}

Oestrogen receptor related proteins (ERRs) affect target gene expression without binding oestradiol. We investigated the functional activity of two splice variant isoforms of ERRß (ERRßS [short], ERRßL [long]) expressed in human endometrium, where they are coexpressed with the oestrogen receptor alpha (ER $\alpha)$. Over-expression of ERRßL enhanced ER $\alpha$-dependent ligand-induced activation of an ERE-luciferase reporter construct, altered the induction of c-myc mRNA and increased proliferation of Ishikawa cells whereas ERRßS was found to reduce these endpoints.

10 Fluorescent recovery after photobleaching (FRAP) revealed that intra-nuclear mobility of YFP-ERRßS was more rapid than YFP-ERRßL. Fluorescence resonance energy transfer (FRET) assays revealed a close association between ERRßL and ER $\alpha$ following addition of ligand. We speculate that ERRßL may alter ER $\alpha$-dependent gene activation by enhancing the recruitment of co-activators. In conclusion, variant isoforms of ERRß have differential effects

15 on ER $\alpha$-dependent gene expression and this has implications for human endometrial cell function. 


\section{Introduction}

The nuclear receptors (NR) play a key role in the regulation of processes involved in reproduction, development, growth and nutrient uptake [1]. A classical view is that NRs act as transcription factors modulating the expression of target genes defined by NR-selective regulatory elements in their promoters; some are classified as ligand-activated (e.g. steroid receptors), while others for which a natural/endogenous ligand has yet to be identified are known as 'orphans' [2]. As many cell types express more than one type of NR an important challenge is elucidating to what extent variations in the intracellular complement of receptors can influence cell or tissue responsiveness to different stimuli.

Oestrogenic ligands bind and activate one of two oestrogen receptors (ER) known as ER $\alpha$ and ERß [3]. They are encoded by separate genes ESR1 (NR3A1) and ESR2 (NR3A2) [4] and arose from a single ancestral receptor by gene duplication [5]. ERs are widely expressed throughout the body and have been implicated in regulation of normal physiological processes including reproduction, cognition and inflammation as well as pathologies including endometriosis and cancer [6]. Members of the NR superfamily share a common arrangement of structural/functional domains including a conserved cysteine-rich region that functions as the DNA-binding domain [7,8]. In addition to the classical ERs three additional oestrogen receptor related genes known as ERR $\alpha$ (ESRRA/ERR1/NR3B1), ERRß (ESRRB/ERR2/NR3B2) and ERR $\gamma(E S R R G / E R R 3 / N R 3 B 3)$ have been identified $[9,10]$. The full-length human ESRRB gene contains 12 exons and three ERRß mRNA splice variants have been identified in human tissues; a short form (exons 1-9), a long form (exons 1-12) and a $\Delta 10$ form that results in a shift in the reading frame and a protein with an altered $\mathrm{C}$ terminus $[11,12]$. Genomic sequence alignment suggests that only the short form exists in species other than primates [11].

It has been proposed that ERRs may modulate both cell fate decisions and cell metabolism [13]. For example, studies in mice have demonstrated that ERR $\alpha$ plays a key role in adaptive thermo genesis and mitochondrial biogenesis [14,15] and ERR $\alpha$ null mice have reduced fat mass [16]. ERR $\gamma$ null mice die during the first week of life due to heart defects [17]. Bookout et al [1] grouped ERRß and ERR $\gamma$ with steroid hormone receptor (SHR) receptors involved in circadian and basic metabolic functions and reported that in the mouse highest levels of expression of ERRß mRNA could be detected in the eye, kidney and heart with lower concentrations in testis, thyroid and parts of the brain. An essential role for ERRß in placental 
development and proliferation of primordial germ cells has been revealed by studies in ERRß null mice $[18,19]$. Recent data has also implicated ERRß in regulating genes critical for the formation and function of the inner ear where it is believed to regulate cell fate decisions [20]. Studies in the human have demonstrated immunoexpression of ERRß in the cochlea and missense mutations in the ESRRB gene have been detected in affected families diagnosed with nonsyndromic hearing impairment [12]. Studies using cells from the mouse have suggested that ERRß may function in conjunction with OCT4 and SOX-2 to promote expression of genes involved in self-renewal and pluripotency [21]. However ERRß has not been detected in human ESCs suggesting that fundamental differences may exist between the role played by this gene in functional maturation of embryonic cells [22]. The impact of ERRß on cell function in oestrogen-dependent human tissues such as the endometrium remains unexplored.

The classical model for ER-dependent regulation of gene expression involves the direct binding of receptor dimers to palindromic DNA sequences known as oestrogen response elements (EREs) and a large number of genes containing EREs have been identified (reviewed in [23]). Genomic studies using breast cancer cells have discovered that binding of $\mathrm{ER} \alpha$ often occurs at enhancer elements and in some cases may depend upon the binding of additional transcription factors such as Sp1 [24]. Once bound to promoter or enhancer elements NR activate transcription by recruitment of additional proteins/protein complexes including members of the general transcription machinery. ERRß contains a core DNA binding domain that exhibits high sequence homology to the sequence in the DNA binding domain of ER $\alpha$ and is reported to bind as a monomer at ERE half sites [5'-AGGTCA-3'] in the major groove of DNA and an upstream 5'-TNA-3' site in the minor groove [25]. An interplay between ERs and ERRs in regulation of gene expression has been claimed on the basis of the results of in vitro studies and it has been proposed that ERRs could interfere with ER-dependent gene expression or participate in co-regulation of target genes such as osteopontin and pS2 [26,27].

30 We have previously demonstrated that ERRß is expressed in multiple cell types within the human endometrium and found evidence of expression of both long and short splice variants of ERRß [28]. In the present study we used an endometrial epithelial cell line to investigate whether expression of ERRßS or ERRßL splice variants can alter oestrogen-responsiveness. We have documented differences in the activity of these isoforms and speculate that the 
presence of additional sequences at the C-terminus of ERRßL influences intra-nuclear mobility and functional activity of the receptor.

\section{Materials and methods}

\subsection{Constructs}

An ERRß cDNA (NM_004452), coding for the long form of ERRß (ERRßL), was purchased from Origene (Rockville, MD, USA). The entire cDNA (ERRßL) was subcloned into the pDC315 plasmid (Microbix, Toronto, ON, Canada) using Bam HI and Eco RI restriction sites. In order to generate the short form of ERRß (ERRßS), a PCR reaction was carried out using primers specific for the sequence encoded by exons 1 to 9 . The last amino acid was turned into a valine and a stop codon was introduced, by substituting the ERRßL sequence GCC TGG with the ERRßS-specific sequence GTA TAG. The primers had Bam HI and Eco RI restriction recognition sites incorporated into their 5' ends and the resulting amplicon was cloned into the pDC315 vector as above. In order to generate proteins with fluorescent protein tags ERRßL and ERRßS cDNAs were subcloned between the Eco RI and Bam HI restriction sites in a yellow fluorescent protein vector (pEYFP-C1, Clontech, Mountain View, CA, USA). ER $\alpha$ cDNA was subcloned between the Eco RI and Bam HI sites of a cyan fluorescent protein expression vector (pECFP-C1, Clontech). A short hairpin siRNA sequence specific for ER $\alpha$ was designed using freely available online tools (available at www.ambion.com). Two complementary oligomers (siER $\alpha$ forward 5'-GAT CCC AGA TTG GCC AGT ACC AAT GTT CAA GAG ACA TTG GTA CTG GCC AAT CTT TTT TTG GAA A-3' and siER $\alpha$ reverse 5'-AGC TTT CCA AAA AAA GAT TGG CCA GTA CCA ATG TCT CTT GAA CAT TGG TAC TGG CCA ATC TGG-3') were purchased from MWG Biotech, annealed and cloned into the pSilencer vector (Ambion) between the Bam HI and Hind III sites. Specific knockdown of ER $\alpha$ protein was confirmed by Western blotting using cells co-transfected with 500ng ER $\alpha$ and 1, 5 or 10nM of plasmid expressing an ER $\alpha$ specific shRNA, or 10nM of a non-specific scrambled shRNA or an shRNA specific for ERß. (Took out mRNA as we don't mention method or results) All constructs were checked by sequencing and purified on caesium chloride gradients using standard methods.

\subsection{Cell culture, transfection and adenoviral infection.}

ER $\alpha$-positive endometrium adenocarcinoma Ishikawa cells (ATCC code 99040201; [29]) were grown at $37^{\circ} \mathrm{C}$ in $5 \% \mathrm{CO}_{2}$, in phenol red DMEM (Gibco), supplemented with $1 \%$ non essential amino acids (Sigma), 2mM L-glutamine (Sigma), 10 ${ }^{5} \mathrm{U} / \mathrm{L}$ penicillin, 100mg/L 
streptomycin (Sigma), 1.25g/L fungizone (Gibco) and 10\% fetal bovine serum (Gibco). They were transferred to phenol red free DMEM (Gibco), containing charcoal stripped fetal calf serum for 48 hours prior to use in order to reduce the presence of steroid ligands and growth factors, this media was also used for all subsequent experiments. COS 7 cells, an African green monkey kidney fibroblast line (ATCC code CRL-1651) were cultured using identical conditions.

Luciferase reporter assays were carried out using cells seeded at $2 \times 10^{5}$ per well in 12 -well plates on day 1 that were transfected on day 2 with JetPEI (QBiogene, Illkirch, France)

10 following the manufacturer's instructions with a 3xERE-tk-luc reporter plasmid (250ng per well, [30]), a tk-Renilla control plasmid to assess transfection efficiency (100ng per well, Promega, Madison, WI, USA) and pDC315 containing either ERRßL or ERRßS (500ng for the dose response experiments and for the study of ERRß basal effect on ERE, 250-750ng made up to 750ng with empty pDC315). In some experiments the mixture also contained 50ng of the shER $\alpha$ construct. After $24 \mathrm{~h}$ transfected cells were treated with vehicle control (DMSO Sigma, final concentration of $10 \mathrm{ppm}$ ), $10^{-11}$ to $10^{-7} \mathrm{M}$ oestradiol-17ß ( $\mathrm{E}_{2}$, Sigma) or the ER $\alpha$-selective agonist propyl pyrazole triol (PPT, Tocris, Ellisville, MO, USA). After a further 24h the cells were washed in PBS, lysed and assayed for luciferase activity using the dual luciferase reporter system (Promega) following the manufacturer's instructions. A sigmoidal dose-response equation was applied to the data using Prism 4 (GraphPad, SanDiego, CA, USA) and statistical significance was assessed using the $95 \%$ confidence interval of the curves generated.

In order to obtain uniform over-expression of ERRß proteins adenoviral vectors containing both the long and short form cDNAs were prepared according to a standard protocol (Microbix). Briefly the cDNA of interest (ERRßS or L) in the pDC315 shuttle vector (see above), was allowed to recombine into the adenoviral genome (pBHGlox $\Delta \mathrm{E} 1,3 \mathrm{Cre}$, Microbix) in Hek293 cells. The resulting viral particles were plaque purified to ensure transgene expression, amplified in Hek293 cells and concentrated using a commercial kit (Vivascience, Hanover, Germany).

For overexpression of cDNAs using adenoviral gene delivery, Ishikawa cells were infected on day 2 with adenovirus at a MOI of 40, after seeding on day 1. Preliminary experiments using a control virus expressing GFP alone indicated that at this MOI $~ 100 \%$ of cells expressed the protein with no evidence of toxicity or cell death. To assess the effect of ERR 
overexpression on endogenous gene targets, RNA was harvested 48 hours after infection and transcript levels measured using qRT-PCR.

Transient transfections using identical concentrations of plasmids expressing ERRßS or ERRßL tagged with yellow fluorescent proteins (Figures 5 and 6) resulted in similar intensities of the fluorescence proteins when measured by confocal microscopy (see section 2.5 below), suggesting that the variant isoforms have a similar stability.

\subsection{Gene expression analysis}

10 RNA was extracted from cell samples using the RNeasy kit (Qiagen, Crawley, UK). Reverse transcription was carried out with random hexamers and analysed by Taqman ${ }^{\mathrm{TM}}$ qRT-PCR on an ABI 7900 Real Time PCR System. Assay on demand ${ }^{\mathrm{TM}}$ primer/probe sets specific for ER $\alpha$ and ERß (Hs00174860_m1 and Hs00230957_m1 respectively) were purchased from Applied Biosystems. Messenger RNA for c-myc was measured using primers designed using the Universal Probe Library (Roche) programme (available at http://qpcr.probefinder.com/organism.jsp) and library probe number 75 (c-myc forward: 5' TTTTTCGGGTAGTGGAAAACC 3' and c-myc reverse: 5'TTCCTGTTGGTGAAGCTAACG 3').

All data was normalised by measuring 18 S ribosomal RNA (assay 4308329) in the same reactions and transcript abundance was expressed as a ratio in comparison with a standard comparator sample of cDNA made from untreated Ishikawa cells that was run on all plates.

\subsection{Cell proliferation assay (MTT)}

Ishikawa cells were seeded at a density of $3 \times 10^{4}$ per well in 96 well plates, in charcoal stripped media (DMEM) and allowed to attach and grow for 24 hours. They were infected with adenoviruses (Rad60 [control], ERRßS or ERRßL at a MOI of 40) in serum free media (DMEM) and 24h later medium was replaced with control serum free medium (DMSO alone) or medium containing $10^{-9} \mathrm{M} \mathrm{E}_{2}$. The impact of $\mathrm{E} 2$ treatment on cell proliferation was assessed after 24 hours using the MTT assay (Roche, Burgess Hill, UK) following the manufacturer's instructions.

\subsection{Live cell imaging.}

Ishikawa cells $\left(4 \times 10^{5}\right)$ were plated in glass bottom dishes (MatTek, Ashland, MA, USA). Cells were transfected with $2 \mu \mathrm{g}$ of plasmid DNA using Jet PEI (as above); plasmids 
ERRßS, YFP-ERRßL). Transfection efficiency was routinely $\sim 30 \%$. The intra-nuclear mobility of YFP-ERRßS and YFP-ERRßL was examined using Fluorescence recovery after photobleaching (FRAP) on an LSM510 metaconfocal (Zeiss) with a stage maintained at $37^{\circ} \mathrm{C}$. Prior to imaging the media was replaced the PBS with $10 \mathrm{mM}$ HEPES buffer (Sigma). In each cell 2 areas within the nucleus were selected and fluorescence was measured before and after bleaching of one of the 2 areas. Recovery of fluorescence was monitored every 3 seconds for 30 seconds. The fluorescence intensity data was normalised for each cell and used in a non-linear regression model, $Y=Y_{\max } \mathrm{x}\left(1-\mathrm{e}^{-\mathrm{Kx}}\right)(\mathrm{GraphPad}$ Prism 4), where the regression coefficient $\mathrm{r}^{2}$ was typically 0.95 . The $\mathrm{Y}_{\max }$ and half-life of recovery values

$10(0.69 / \mathrm{K})$ were averaged for at least 20 cells per treatment.

In order to determine whether the ERRß variant proteins were capable of forming heterodimers with ER $\alpha$, fluorescence resonance energy transfer (FRET) assays were conducted using Ishikawa cells that had been transfected with expression plasmids containing YFP-ERRßL or YFP-ERRßS together with a cyan fluorescent protein-tagged ER $\alpha$ (CFP$\mathrm{ER} \alpha$ ). The intensity of the CFP signal was monitored following bleaching of the YFP molecules using an Argon2 laser (514 nm). The FRET efficiency (change in CFP signal normalised to the YFP signal) was measured for at least 10 cells per treatment. Cells treated with $10^{-8}$ M PPT were incubated for 20 minutes before measurements started.

In order to validate the procedure, experiments were carried out with cells transfected with a positive control pCY24 plasmid (a generous gift from Dr Rory Duncan, University of Edinburgh), consisting of the CFP and YFP cDNA sequences cloned in frame with a 72bp (24 amino acid) spacer. Typical FRET efficiency values for this positive control were around $30 \%$. Negative control experiments were carried out with cells co-transfected with the pECFP and pEYFP plasmids, to check no FRET signal was generated when non-interacting fluorophores were present in the same cell.

\subsection{Statistical analysis}

30 Data from all experiments were averaged (3 to 5 repeats) where possible. When the results of all experiments were similar but differed greatly in the dynamic range of the response, a representative experiment was shown and the statistics were carried out on the replicates. All statistical analysis was carried out using Prism 4 (GraphPad). Data normality was assessed and where required one- (treatment) or two-way (treatment and time) ANOVA, Kruskal-Wallis or Friedman tests were used, with a level of significance of $5 \%$. 


\section{Results.}

\subsection{Impact of ERRß variants on ERE-dependent reporter gene activity}

In order to determine what impact ERRßL and ERRßS have on ERE-dependent gene expression ER $\alpha$-positive Ishikawa cells were co-transfected with a luciferase reporter construct under the control of a promoter containing 3 copies of a consensus ERE, together with an expression plasmid containing ERRßS or ERRßL. Overexpression of ERRßS and ERRßL resulted in a modest constitutive expression of luciferase that did not reach statistical significance (Figure 1A). Consistent with expression of ER $\alpha$ in this Ishikawa cell line incubation of cells with E2 (Figure 1B) or PPT (Figure 1C) resulted in a dose dependent increase in expression of luciferase to $\sim 15$ fold over control (no ligand) in the presence of $10^{-}$ $7 \mathrm{M}$ E2 or PPT. Transfection of cells with ERRßS or ERRßL had a differential effect on ligand-induced expression of luciferase. Whereas ERRßS blunted ligand-induced expression of luciferase and caused the plateau (Ymax) value to decrease (from 17.4 to 5.5 for E2 and from 16.1 to 7.8 fold for PPT) transfection of cells with ERRßL resulted in an increase in the Ymax (to 22 fold for both agonists). The $\mathrm{EC}_{50}$ value, a reflection of the receptor-ligand interaction, remained constant between treatments (around $3 \times 10^{-10} \mathrm{M}$ for both ligands). The use of increasing amounts of ERRßL (100, 250 and 500ng) produced a gradual shift upwards of the sigmoid plateau values, suggesting the transcriptional enhancement is ERRbL dependent (Figure 1D). In order to confirm that ligand-dependent gene expression required activation of ER $\alpha$ the experiments with ERRßL were repeated in the presence or absence of an ER $\alpha$-specific shRNA (Figure 1E). Partial ablation of the response to PPT, caused by reduced concentrations of ER $\alpha$ as a result of the introduction of the specific shRNA resulted in a decrease of the plateau value (from 12.7 to 2.4 fold maximal activation). Overexpression of ERRßL partially rescued this response (from 2.4 to 6.8 fold) (Figure 1F). The validity of using sigmoid curve regression analysis to assess ER $\alpha$-mediated induction was confirmed by demonstrating that the regression coefficient values $\left(\mathrm{r}^{2}\right)$ were higher than 0.95 .

\subsection{Impact of ERR $\beta$ variants on expression of c-myc}

In breast cancer cells expression of c-myc is rapidly up-regulated in response to oestrogentreatment. The c-myc promoter does not contain an oestrogen-response element [31] and upregulation by ER $\alpha$ appears to involve co-recruitment of Sp1 transcription factors [32]. Over expression of either ERRßS or ERRßL using an adenoviral delivery system did not have a significant impact on the basal expression of c-myc mRNA compared with control 
(uninfected) cells or those infected with the Rad60 viral control (Figure 2A). However when a time course experiment was conducted in order to explore the impact of ERRß variants on E2-mediated expression of c-myc differences emerged (Figure 2B). In the presence of Rad60 or ERRßS, maximal expression of c-myc mRNA ( 4 fold compared with control) was detected at $60 \mathrm{~min}$ after the addition of E2. However over-expression of ERRßL increased expression of c-myc induced in response to E2 at $90 \mathrm{~min}(\mathrm{p}<0.001)$. A similar pattern of response was observed when treatments were carried out using PPT in place of E2, although the data did not reach statistical significance (not shown).

\subsection{Impact of ERRß variants on cell proliferation}

Oestrogens act as potent mitogens and c-myc plays a key role in the induction of cell cycle progression in response to oestrogen [33] therefore as a complement to the studies presented above the impact of ERRß variants on E2-induced cell proliferation was investigated 24h after addition of ligand (Figure 3). Over expression of ERRßL had a significant $(\mathrm{p}<0.05)$ positive impact on cell proliferation in the presence of E2 whereas ERRßS did not.

\subsection{Impact of ERR $\beta$ variants on concentration of ER $\alpha$ and $E R \beta m R N A s$}

To determine whether overexpression of ERR 3 was altering oestrogen responsiveness by modulating expression of ER $\alpha$ or ERß total $\mathrm{mRNA}$ for each receptor was determined by qRT-PCR using cells infected $48 \mathrm{~h}$ previously with control adenovirus or that containing ERRßS or ERRßL; no significant differences in total amounts of transcript were detected (Figure 4A, B). Western analysis did not reveal any difference in expression of ER $\alpha$ (not shown). These results are consistent with the lack of effect of ERRßS and ERRßL on the $\mathrm{EC}_{50}$ values obtained in the dose response experiments (see above, Figure 1C).

\subsection{FRAP analysis}

Intranuclear mobility of ERRßS and ERRßL was compared by performing FRAP analysis using YFP-tagged receptors transfected into COS7 or Ishikawa cells (Figure 5A). A striking difference between the variants was noted when the rate of recovery into the bleached area of the nucleus was compared. Whereas ERRßS was highly mobile the normalised recovery rate of ERRßL was slower in both cell lines studied. Similar results were obtained regardless of whether YFP-ERR $\beta$ constructs were transfected into ER $\alpha$ negative COS7 (Figure 5B) or ER $\alpha$ positive Ishikawa (Figure 5C) cells. Treatment of Ishikawa cells with the ER $\alpha$ specific PPT $\left(10^{-8} \mathrm{M}\right)$ had no significant impact on the intra-nuclear mobility of ERRßS or ERRßL 


\subsection{FRET analysis}

To investigate whether the impact of ERRß on oestrogen responsiveness of the Ishikawa cells might be due to formation of ERRß/ER $\alpha$ heterodimers FRET analysis was carried out comparing control cells (no ligand) with those incubated in the presence of PPT. In control cells no measurable FRET signal was observed after co-transfection with CFP-ER $\alpha$ and either YFP-ERRßS or YFP-ERRßL. After incubation of cells with PPT, there was a significant increase in FRET signal between ER $\alpha$ and ERRßL $(\sim 12 \%)$ whereas there was no significant increase in the FRET signal in the presence of ER $\alpha$ and ERRBS (Figure 6). We used PPT for these experiments to ensure that ligand binding was selective for ER $\alpha$; a similar but non-significant trend was obtained when E2 was used in the place of PPT (not shown). In line with expectations FRET signals with positive (pCY24) and negative (pECFP and pEYFP) control plasmids were $\sim 30 \%$ and $0 \%$ respectively (Figure 6 )

\section{Discussion.}

The human endometrium is an oestrogen target tissue and during the follicular phase of the cycle rising levels of circulating oestrogens increase the rate of endometrial cell proliferation [34] an observation that can be replicated using explant cultures of postmenopausal endometrium [35]. Studies in rodent models suggest that both proliferation and increased expression of progesterone receptor are mediated by ER $\alpha$ [36]. The current studies were initiated following the observation that mRNAs encoding both ERRßL and $\mathrm{S}$ are expressed in human endometrium [28] and by reports in the literature that expression of ERRs can have an impact on ER-dependent gene expression (reviewed in [9]). We used a variety of approaches to determine whether expression of ERRß isoforms in endometrial cells might have an impact on their response to oestradiol and whether ERRß could alter the activity of ER $\alpha$ in these cells.

Several studies have investigated the impact of ERRs on gene transcription [26,37-42]. The majority of these studies have involved transient transfection using a variety of cell lines. For example, Xie et al [37] reported that ERRß (the sequence used corresponded to the ERRßS isoform used in the current study) activated a reporter construct containing a tk-ERE when they were co-transfected into CV-1 cells $[10$ fold over controls using $2 \mu \mathrm{g}$ of plasmid plus $5 \mu \mathrm{g}$ reporter]. Activation of the ERE promoter was dependent upon the amount of ERRß transfected into HeLa cells but independent of E2; ERRß was also able to activate a reporter 
containing a copy of the palindromic thyroid response element [5'-

TCAGGTCATGACCTGA-3'] in a ligand independent manner [37]. In the current study we investigated whether ERRßL and ERRßS could activate expression using a reporter construct containing three copies of the vitellogenin ERE [3xGGTCAcagTGACC] [30] in endometrial Ishikawa cells. We found that over expression of ERRßS and ERRßL (500ng) resulted in a modest yet non-significant induction of the reporter gene. These results contrast with previous work, where constitutive activity was reported $[11,27]$. The apparent contradictions in the data may reflect differences in the environment of the cells used in the studies. For example, Zhou et al [11] performed their reporter assays in MCF-7 derived ER $\alpha$ negative cells whereas Lu et al [27] used HeLa cells transfected with ERR constructs and a luciferase reporter under the control of the pS2 gene promoter. We speculate that the reduction in the ER $\alpha$-dependent induction of the ERE-luciferase reporter observed in the presence of ERRßS (Fig. 1B and 1C) may be due to 'squelching' associated with competition for nuclear receptor cofactors [43].

A novel finding of the present study was the differential impact of the two ERRß variant isoforms on ER $\alpha$-dependent gene activation. Initial observations were based on studies using the 3xERE reporter assay and these were complemented and extended by examining expression of the oestrogen-regulated gene c-myc and the impact on cell proliferation using the MTT assay system. In all cases increased expression of ERRßL in ER $\alpha$-positive Ishikawa cells augmented the response to E2. We considered a number of different explanations for this observation. Firstly since the Ishikawa cell line we used for these experiments expresses both ER $\alpha$ and ERß (our unpublished results and [29]) we determined whether introduction of ERRßs into the cells might have a direct impact on expression of either receptor subtype but expression remained unchanged. Secondly, we established that the impact of ERRßL on the response to E2 was linked to the presence of ER $\alpha$ in these cells by demonstrating that the augmented response observed in the presence of E2 could be mimicked by the ER $\alpha$-selective agonist PPT and that this response was reduced when the amount of ER $\alpha$ protein present in the cells was reduced by RNA interference. Notably, in

30 their study Zhou et al [11] used an ER $\alpha$-negative MCF-7 cell line and in their assays addition of E2 to cells transfected with ERRß constructs had no impact on ERE-dependent reporter gene activation . 
Formation of homo- or hetero-dimers is a key feature of NR signalling and recent studies using mouse heart have reported that ERR $\alpha$ and ERR $\gamma$ can bind a common set of promoters and act as non-obligatory heterodimers at these sites [13]. ER $\alpha$ and ER $\beta$ can form heterodimers at ERE sequences [44] and ER $\alpha$ is reported to be unable to bind an ERE as a monomer [45]. Previous studies have reported evidence that a physical association occurs between ER $\alpha$ and ERR $\alpha$, when recombinant proteins were co-incubated in vitro [46].

In order to establish whether the impact of ERRßL on ER $\alpha$-dependent gene expression reflected a physical association between the receptors we used two well-established in vitro imaging methods, FRAP and FRET [47]. FRAP was used to compare the intra-nuclear mobility of ERRß variants in the presence and absence of E2 and PPT in both ER $\alpha$ - positive and ER $\alpha$-negative cells. In both cell types ERRßS and ERRßL proteins tagged with YFP were detected within the cell nuclei with no evidence of significant expression in the cytoplasmic compartment for either variant. Following bleaching of a small region of the nucleus recovery of ERRßS was more rapid than that of ERRßL; results were similar in the two cell lines and in the Ishikawa cells there was no evidence that the rate of recovery was changed following addition of E2 or PPT. Parallel studies in our own laboratory using a YFPtagged ER $\alpha$ construct have demonstrated that the receptor is highly mobile in the absence of ligand but following addition of E2 or PPT the rate of recovery into the bleached area is dramatically reduced (Fitzgerald and Saunders unpublished). These results are in agreement with other studies on the impact of ligand binding on members of the NR family including $\mathrm{ER} \alpha[48]$ and androgen receptor [49]. Transient immobilisation within the nucleus of ligandbound NRs is believed to reflect association of the proteins with the nuclear matrix [49] and studies on activity of ARs have demonstrated that both the ligand binding and DNA binding domains are required for DNA binding (reviewed in [47]).

Mobility of ERRBS was not altered by addition of ligands to ER $\alpha$ positive cells and this finding was backed up by FRET analysis showing that there was no increase in FRET efficiency between ER $\alpha$ and ERRßS suggesting that the proteins were not closely associated with each other within the nucleus. In contrast, FRET efficiency between ER $\alpha$ and ERRßL was increased following addition of E2 or PPT a finding that implies the CYP and YFP protein tags on the proteins were within 10 angstroms of each other. Although this finding might be consistent with formation of a heterodimer between the two proteins alternative explanations need to be considered. For example, is ERRßL typically associated with the 
chromatin and therefore when ligand-activated ER $\alpha$ becomes more closely associated with the same nuclear sub-compartment does this account for the increase in FRET? Alternatively does the presence of ERRßL augment protein-protein interactions in pre-initiation complex formed by ER $\alpha$ homodimers and receptor co-activators? We speculate that in tissues such as the human endometrium, where ER $\alpha$, ERRßS and ERRßL are all expressed in multiple cell types [28], the former may act as a repressor of ER $\alpha$-dependent gene activation, whereas the latter may augment the impact of oestrogens in ER $\alpha$-positive cells.

Our data suggest that the presence of an F-domain consisting of 67 amino acids at the Cterminus of the ERRßL [11] has a marked impact on the intra-nuclear mobility of the protein and plays a key role in the ERRß-dependent increase in ER $\alpha$-mediated transcription. Not all members of the nuclear receptor superfamily have an F domain and in those that do its length varies from as little as 11 amino acids in the androgen receptor, to more than 90 amino acids in hepatocyte nuclear factor 4 (HNF4 $\alpha$, NR2A1). Compared with many papers containing detailed analysis of the ligand-binding domain this region has received relatively little attention. Two of the best-studied F domains are those found in ER $\alpha$ [50] and HNF1 $\alpha$ [51]. The F-domain of ER $\alpha$ contains $\sim 45$ amino acids and in silico modelling studies suggest that it contains an alpha helix and two extended regions with a similar secondary structure to the Fdomain of HNF1 $\alpha$ [52]. Yang et al [53] have reported that removal of 24 amino acids at the $\mathrm{C}$-terminus of the F-domain resulted in a 5 fold increase in dimerisation of E2-bound ER $\alpha$ and increased interactions with SRC-1 in yeast two hybrid assays. In contrast studies using HeLa cells have demonstrated that sequences within this region can have a positive impact on the ability of the receptor to activate ERE-dependent reporter genes [50,54], can promote interactions with co-factors including TAF-1ß [55] and SRC-1 [54] and is essential for interaction with $\mathrm{Sp}-1$ proteins at GC-rich promoters [56]. The large F-domain present on HNF4 $\alpha 1$ appears to interact directly with the ligand-binding domain acting as a repressor by blocking binding of the transcriptional regulators SRC1a, GRIP1, p300 and CBP. Whereas in the HNF 2 splice isoform a 10 amino acid insert into the F-domain partially relieves this inhibition [51], highlighting the impact of alternative splicing on receptor activity something also observed in hERß where replacement of 61 amino acids, including the F-domain $(\sim 30$ amino acids) at the $\mathrm{C}$-terminus of the protein, with an alternative 26 amino acids completely abolishes E2-dependent gene activation [57]. Bioinformatic analysis of the ERRßL F-domain failed to identify any evidence of putative phosphorylation sites (not shown) or secondary structures such as alpha helices using the DAS program 
(http://www.sbc.su.se/ miklos/DAS/). Therefore additional investigations using methods such as site directed mutagenesis will be necessary if we are to determine which amino-acids within the F domain of ERRßL are critical for ER $\alpha$-dependent gene activation.

The short form of ERRß can repress transcriptional activity of Nrf2 on the antioxidant response element and alter the subcellular distribution of Nrf2 [41]. ERRß and Nrf2 could be co-precipitated consistent with the formation of a protein complex containing both proteins and in the discussion of their paper the authors suggested that ERRßS might have an impact on Nrf2 transcriptional activity by bringing co-repressors into this complex. ERRßL was not investigated in their studies [41]. ERR $\alpha$, ERRß and ERR $\gamma$ can also bind to HIF1 $\alpha / \mathrm{HIF} 1 \beta$ heterodimers, enhance transcriptional activity of a HIF1-luc reporter gene as well as expression of HIF1 $\alpha$ regulated genes including PGK-1 [42]. The results in these papers are interesting not only because they demonstrate that ERRß may have impacts on gene expression beyond those involving ER $\alpha$ but also because of the suggestion that ERRß may influence HIF-1 dependent gene expression by boosting the number of co-activators in the transcription complex [42]. A similar mechanism may apply to the enhanced activity of ER $\alpha$ dependent gene expression we observed in the presence of ERRßL since both ERRs and ER $\alpha$ are reported to bind co-activators including PGC-1 $\alpha$ and SRC-1.

In conclusion, our results suggest that expression of ERRßL can augment ER $\alpha$-dependent gene activation whereas ERRBS cannot. This result is another example of differential regulation of nuclear receptor activity as a result of alternative splicing. The results highlight a critical role for the F domain of ERRßL and we speculate that ERRßL may enhance cofactor recruitment by ligand-activated ER $\alpha$.

\section{Acknowledgements}

The authors thank the following for technical assistance: Douglas Gibson and Karen Kerr for cell cultures, Mike Millar, Sheila MacPherson and Carol Fitzgerald for assistance with confocal microscopy and FRAP analysis. We are grateful to Professor Karen Chapman for her many helpful suggestions and insightful discussion and to Professor Robert Millar for constructive comments on the results. 


\section{References}

[1] Bookout, A.L., Jeong, Y., Downes, M., Yu, R.T., Evans, R.M. and Mangelsdorf, D.J. (2006) Anatomical profiling of nuclear receptor expression reveals a hierarchical transcriptional network. Cell 126, 789-99.

5 [2] Giguere, V. (1999) Orphan nuclear receptors: from gene to function. Endocr Rev 20, 689-725.

[3] Nilsson, S., Makela, S., Treuter, E., Tujague, M., Thomsen, J., Andersson, G., Enmark, E., Pettersson, K., Warner, M. and Gustafsson, J. (2001) Mechanisms of estrogen action. Physiol Rev 81, 1535-65.

10 [4] Enmark, E., Pelto-Huikko, M., Grandien, K., Lagercrantz, S., Lagercrantz, J., Fried, G., Nordenskjold, M. and Gustafsson, J.A. (1997) Human estrogen receptor beta-gene structure, chromosomal localization, and expression pattern. J Clin Endocrinol Metab $82,4258-65$.

[5] Thornton, J.W. (2001) Evolution of vertebrate steroid receptors from an ancestral estrogen receptor by ligand exploitation and serial genome expansions. Proc Natl Acad Sci U S A 98, 5671-6.

[6] Nilsson, M., Dahlman-Wright, K. and Gustafsson, J.A. (2004) Nuclear receptors in disease: the oestrogen receptors. Essays Biochem 40, 157-67.

[7] Evans, R.M. (1988) The steroid and thyroid hormone receptor superfamily. Science 240, 889-95.

[8] (1999) A unified nomenclature system for the nuclear receptor superfamily. Cell 97, 161-3.

[9] Giguere, V. (2002) To ERR in the estrogen pathway. Trends Endocrinol Metab 13, 220-5.

[10] Tremblay, A.M. and Giguere, V. (2007) The NR3B subgroup: an ovERRview. Nucl Recept Signal 5, e009.

[11] Zhou, W., Liu, Z., Wu, J., Liu, J.H., Hyder, S.M., Antoniou, E. and Lubahn, D.B. (2006) Identification and characterization of two novel splicing isoforms of human estrogen-related receptor beta. J Clin Endocrinol Metab 91, 569-79.

[12] Collin, R.W., Kalay, E., Tariq, M., Peters, T., van der Zwaag, B., Venselaar, H., Oostrik, J., Lee, K., Ahmed, Z.M., Caylan, R., Li, Y., Spierenburg, H.A., Eyupoglu, E., Heister, A., Riazuddin, S., Bahat, E., Ansar, M., Arslan, S., Wollnik, B., Brunner, H.G., Cremers, C.W., Karaguzel, A., Ahmad, W., Cremers, F.P., Vriend, G., Friedman, T.B., Riazuddin, S., Leal, S.M. and Kremer, H. (2008) Mutations of ESRRB encoding estrogen-related receptor beta cause autosomal-recessive nonsyndromic hearing impairment DFNB35. Am J Hum Genet 82, 125-38.

[13] Dufour, C.R., Wilson, B.J., Huss, J.M., Kelly, D.P., Alaynick, W.A., Downes, M., Evans, R.M., Blanchette, M. and Giguere, V. (2007) Genome-wide orchestration of cardiac functions by the orphan nuclear receptors ERRalpha and gamma. Cell Metab 5, 345-56.

[14] Villena, J.A., Hock, M.B., Chang, W.Y., Barcas, J.E., Giguere, V. and Kralli, A. (2007) Orphan nuclear receptor estrogen-related receptor alpha is essential for adaptive thermogenesis. Proc Natl Acad Sci U S A 104, 1418-23.

[15] Huss, J.M., Imahashi, K., Dufour, C.R., Weinheimer, C.J., Courtois, M., Kovacs, A., Giguere, V., Murphy, E. and Kelly, D.P. (2007) The nuclear receptor ERRalpha is required for the bioenergetic and functional adaptation to cardiac pressure overload. Cell Metab 6, 25-37.

[16] Luo, J., Sladek, R., Carrier, J., Bader, J.A., Richard, D. and Giguere, V. (2003) Reduced fat mass in mice lacking orphan nuclear receptor estrogen-related receptor alpha. Mol Cell Biol 23, 7947-56.

[17] Alaynick, W.A., Kondo, R.P., Xie, W., He, W., Dufour, C.R., Downes, M., Jonker, J.W., Giles, W., Naviaux, R.K., Giguere, V. and Evans, R.M. (2007) ERRgamma 
directs and maintains the transition to oxidative metabolism in the postnatal heart. Cell Metab 6, 13-24.

[18] Luo, J., Sladek, R., Bader, J.A., Matthyssen, A., Rossant, J. and Giguere, V. (1997) Placental abnormalities in mouse embryos lacking the orphan nuclear receptor ERRbeta. Nature 388, 778-82.

[19] Mitsunaga, K., Araki, K., Mizusaki, H., Morohashi, K., Haruna, K., Nakagata, N., Giguere, V., Yamamura, K. and Abe, K. (2004) Loss of PGC-specific expression of the orphan nuclear receptor ERR-beta results in reduction of germ cell number in mouse embryos. Mech Dev 121, 237-46.

[20] Chen, J. and Nathans, J. (2007) Estrogen-related receptor beta/NR3B2 controls epithelial cell fate and endolymph production by the stria vascularis. Dev Cell 13, 325-37.

[21] Feng, B., Jiang, J., Kraus, P., Ng, J.H., Heng, J.C., Chan, Y.S., Yaw, L.P., Zhang, W., Loh, Y.H., Han, J., Vega, V.B., Cacheux-Rataboul, V., Lim, B., Lufkin, T. and Ng, H.H. (2009) Reprogramming of fibroblasts into induced pluripotent stem cells with orphan nuclear receptor Esrrb. Nat Cell Biol 11, 197-203.

[22] Xie, C.Q., Jeong, Y., Fu, M., Bookout, A.L., Garcia-Barrio, M.T., Sun, T., Kim, B.H., Xie, Y., Root, S., Zhang, J., Xu, R.H., Chen, Y.E. and Mangelsdorf, D.J. (2009) Expression Profiling of Nuclear Receptors in Human and Mouse Embryonic Stem Cells. Mol Endocrinol.

[23] O'Lone, R., Frith, M.C., Karlsson, E.K. and Hansen, U. (2004) Genomic targets of nuclear estrogen receptors. Mol Endocrinol 18, 1859-75.

[24] Kininis, M. and Kraus, W.L. (2008) A global view of transcriptional regulation by nuclear receptors: gene expression, factor localization, and DNA sequence analysis. Nucl Recept Signal 6, e005.

[25] Gearhart, M.D., Dickinson, L., Ehley, J., Melander, C., Dervan, P.B., Wright, P.E. and Gottesfeld, J.M. (2005) Inhibition of DNA binding by human estrogen-related receptor 2 and estrogen receptor alpha with minor groove binding polyamides. Biochemistry 44, 4196-203.

30 [26] Vanacker, J.M., Pettersson, K., Gustafsson, J.A. and Laudet, V. (1999) Transcriptional targets shared by estrogen receptor- related receptors (ERRs) and estrogen receptor (ER) alpha, but not by ERbeta. Embo J 18, 4270-9.

[27] Lu, D., Kiriyama, Y., Lee, K.Y. and Giguere, V. (2001) Transcriptional regulation of the estrogen-inducible pS2 breast cancer marker gene by the ERR family of orphan nuclear receptors. Cancer Res 61, 6755-61.

[28] Bombail, V., MacPherson, S., Critchley, H.O. and Saunders, P.T. (2008) Estrogen receptor related beta is expressed in human endometrium throughout the normal menstrual cycle. Hum Reprod 23, 2782-90.

[29] Nishida, M., Kasahara, K., Kaneko, M., Iwasaki, H. and Hayashi, K. (1985)

[Establishment of a new human endometrial adenocarcinoma cell line, Ishikawa cells, containing estrogen and progesterone receptors]. Nippon Sanka Fujinka Gakkai Zasshi 37, 1103-11.

[30] Hall, J.M. and McDonnell, D.P. (1999) The estrogen receptor beta-isoform (ERbeta) of the human estrogen receptor modulates ERalpha transcriptional activity and is a key regulator of the cellular response to estrogens and antiestrogens. Endocrinology 140, 5566-78.

[31] Dubik, D. and Shiu, R.P. (1992) Mechanism of estrogen activation of c-myc oncogene expression. Oncogene 7, 1587-94.

[32] Miller, T.L., Jin, Y., Sun, J.M., Coutts, A.S., Murphy, L.C. and Davie, J.R. (1996) Analysis of human breast cancer nuclear proteins binding to the promoter elements of the c-myc gene. J Cell Biochem 60, 560-71. 
[33] Musgrove, E.A., Sergio, C.M., Anderson, L.R., Inman, C.K., McNeil, C.M., Alles, M.C., Gardiner-Garden, M., Ormandy, C.J., Butt, A.J. and Sutherland, R.L. (2008) Identification of downstream targets of estrogen and c-myc in breast cancer cells. Adv Exp Med Biol 617, 445-51.

[34] Brenner, R.M., Slayden, O.D., Rodgers, W.H., Critchley, H.O., Carroll, R., Nie, X.J. and Mah, K. (2003) Immunocytochemical assessment of mitotic activity with an antibody to phosphorylated histone $\mathrm{H} 3$ in the macaque and human endometrium. Hum Reprod 18, 1185-93.

[35] Punyadeera, C., Kamps, R., Defrere, S., Dijcks, F., de Goeij, A., Ederveen, A., Dunselman, G. and Groothuis, P. (2008) Effects of selective oestrogen receptor modulators on proliferation in tissue cultures of pre- and postmenopausal human endometrium. J Steroid Biochem Mol Biol.

[36] Couse, J.F. and Korach, K.S. (1999) Estrogen receptor null mice: what have we learned and where will they lead us? Endocr Rev 20, 358-417.

[37] Xie, W., Hong, H., Yang, N.N., Lin, R.J., Simon, C.M., Stallcup, M.R. and Evans, R.M. (1999) Constitutive activation of transcription and binding of coactivator by estrogen-related receptors 1 and 2. Mol Endocrinol 13, 2151-62.

[38] Zhang, Y., Ma, K., Sadana, P., Chowdhury, F., Gaillard, S., Wang, F., McDonnell, D.P., Unterman, T.G., Elam, M.B. and Park, E.A. (2006) Estrogen-related receptors stimulate pyruvate dehydrogenase kinase isoform 4 gene expression. $\mathrm{J}$ Biol Chem 281, 39897-906.

[39] Zhang, Z. and Teng, C.T. (2000) Estrogen receptor-related receptor alpha 1 interacts with coactivator and constitutively activates the estrogen response elements of the human lactoferrin gene. J Biol Chem 275, 20837-46.

[40] Zhang, Z. and Teng, C.T. (2001) Estrogen receptor alpha and estrogen receptorrelated receptor alphal compete for binding and coactivator. Mol Cell Endocrinol 172, 223-33.

[41] Zhou, W., Lo, S.C., Liu, J.H., Hannink, M. and Lubahn, D.B. (2007) ERRbeta: A potent inhibitor of Nrf2 transcriptional activity. Mol Cell Endocrinol 278, 52-62.

[42] Ao, A., Wang, H., Kamarajugadda, S. and Lu, J. (2008) Involvement of estrogenrelated receptors in transcriptional response to hypoxia and growth of solid tumors. Proc Natl Acad Sci U S A 105, 7821-6.

[43] Min, G., Kim, H., Bae, Y., Petz, L. and Kemper, J.K. (2002) Inhibitory cross-talk between estrogen receptor (ER) and constitutively activated androstane receptor (CAR). CAR inhibits ER-mediated signaling pathway by squelching p160 coactivators. J Biol Chem 277, 34626-33.

[44] Cowley, S.M., Hoare, S., Mosselman, S. and Parker, M.G. (1997) Estrogen receptors alpha and beta form heterodimers on DNA. J Biol Chem 272, 19858-62.

[45] Klinge, C.M., Bodenner, D.L., Desai, D., Niles, R.M. and Traish, A.M. (1997)

Binding of type II nuclear receptors and estrogen receptor to full and half-site estrogen response elements in vitro. Nucleic Acids Res 25, 1903-12.

[46] Yang, N., Shigeta, H., Shi, H. and Teng, C.T. (1996) Estrogen-related receptor, hERR1, modulates estrogen receptor-mediated response of human lactoferrin gene promoter. J Biol Chem 271, 5795-804.

[47] van Royen, M.E., Farla, P., Mattern, K.A., Geverts, B., Trapman, J. and Houtsmuller, A.B. (2009) Fluorescence Recovery After Photobleaching (FRAP) to Study Nuclear Protein Dynamics in Living Cells. Methods Mol Biol 464, 363-85.

[48] Stenoien, D.L., Patel, K., Mancini, M.G., Dutertre, M., Smith, C.L., O'Malley, B.W. and Mancini, M.A. (2001) FRAP reveals that mobility of oestrogen receptor-alpha is ligand- and proteasome-dependent. Nat Cell Biol 3, 15-23.

[49] Marcelli, M., Stenoien, D.L., Szafran, A.T., Simeoni, S., Agoulnik, I.U., Weigel, N.L., Moran, T., Mikic, I., Price, J.H. and Mancini, M.A. (2006) Quantifying effects 
of ligands on androgen receptor nuclear translocation, intranuclear dynamics, and solubility. J Cell Biochem 98, 770-88.

[50] Skafar, D.F. and Koide, S. (2006) Understanding the human estrogen receptor-alpha using targeted mutagenesis. Mol Cell Endocrinol 246, 83-90.

[51] Sladek, F.M., Ruse, M.D., Jr., Nepomuceno, L., Huang, S.M. and Stallcup, M.R. (1999) Modulation of transcriptional activation and coactivator interaction by a splicing variation in the $\mathrm{F}$ domain of nuclear receptor hepatocyte nuclear factor 4alpha1. Mol Cell Biol 19, 6509-22.

[52] Schwartz, J.A., Zhong, L., Deighton-Collins, S., Zhao, C. and Skafar, D.F. (2002) Mutations targeted to a predicted helix in the extreme carboxyl-terminal region of the human estrogen receptor-alpha alter its response to estradiol and 4-hydroxytamoxifen. J Biol Chem 277, 13202-9.

[53] Yang, J., Singleton, D.W., Shaughnessy, E.A. and Khan, S.A. (2008) The F-domain of estrogen receptor-alpha inhibits ligand induced receptor dimerization. Mol Cell Endocrinol 295, 94-100.

[54] Koide, A., Zhao, C., Naganuma, M., Abrams, J., Deighton-Collins, S., Skafar, D.F. and Koide, S. (2007) Identification of regions within the F domain of the human estrogen receptor alpha that are important for modulating transactivation and proteinprotein interactions. Mol Endocrinol 21, 829-42.

20 [55] Loven, M.A., Muster, N., Yates, J.R. and Nardulli, A.M. (2003) A novel estrogen receptor alpha-associated protein, template-activating factor Ibeta, inhibits acetylation and transactivation. Mol Endocrinol 17, 67-78.

[56] Kim, K., Thu, N., Saville, B. and Safe, S. (2003) Domains of estrogen receptor alpha (ERalpha) required for ERalpha/Sp1-mediated activation of GC-rich promoters by estrogens and antiestrogens in breast cancer cells. Mol Endocrinol 17, 804-17.

[57] Sierens, J.E., Scobie, G.A., Wilson, J. and Saunders, P.T. (2004) Cloning of oestrogen receptor beta from Old and New World primates: identification of splice variants and functional analysis. J Mol Endocrinol 32, 703-18. 


\section{Figure legends}

Figure 1: ERRBL and ERRBS exhibit minimal constitutive activity but have differential effects on ERE-dependent luciferase reporter gene expression following treatment of cells with agonists, in an $\mathrm{ER} \alpha$ specific fashion.

Ishikawa cells were transfected with 500ng of plasmids expressing ERRßS or ERRßL (A), together with the ERE-luciferase plasmid. Reporter gene activation (luciferase activity) was measured after $48 \mathrm{~h}$. The graph represents the average from 5 experiments. Luciferase activity was not significantly increased: $\mathrm{p}=0.23$ by Kruskal-Wallis test. Panels B and C: Ishikawa cells were transfected as above with 500ng of ERRß or the empty pDC vector and treated with increasing doses of E2 (B) or the ER $\alpha$ specific agonist PPT (C). The resulting increase in luciferase activity was converted to fold induction using the basal DMSO luciferase value and a sigmoid regression was applied (see method section). The regression data indicates the 95\% confidence of the Ymax (plateau) values do not overlap indicating a statistical difference, with no change in the EC50 values. Each experiment was performed in duplicate, replicated 3 times and gave the same result. Panel D: Ishikawa cells were transfected as above with increasing amounts of ERRß long form (100, 250 or 500ng) or the empty pDC vector. The final plasmid concentration was kept constant to 500ng using pDC vector. The data was analysed as for panels B and $\mathrm{C}$ and showed that the enhancement of ERE-luciferase induction was more pronounced with increasing amounts of ERRßL. Panel E: Validation of sh-RNA dependent knockdown of ER $\alpha$. Image shows Western analysis of ER $\alpha$ protein. Note that transient transfection with an ER $\alpha$ plasmid increased expression of the protein and that this was reduced in concentration dependent manner by co-transfection with a shRNA specific for $\mathrm{ER} \alpha(\operatorname{shER} \alpha)$ but not by a scrambled non-specific shRNA or a shRNA directed against ERß.

Panel F: Ishikawa cells were transfected with 500ng empty pDC vector or ERRß long form, in the presence or absence of 50ng shER $\alpha$ plasmid (see panel E) were treated with various concentrations of PPT for 24 hours. The 95\% confidence interval of the Ymax regression values did not overlap, with no change in the EC50 values. This representative experiment was performed 4 times and gave similar results. All data was expressed as mean \pm SEM.

Figure 2: Differential effect of ERRß short and long forms on the induction kinetics of c-myc, in response to treatment of cells with $\mathrm{E} 2$.

Ishikawa cells were infected with adenoviral particles at a MOI of 40 and expression of cmyc mRNA was assessed by qRT-PCR; data represents the average of 3 independent experiments (expressed as mean \pm SEM). A) Over expression of Rad60 (control), ERRßS or 
ERRßL adenoviral particles had no significant impact on the amount of c-myc mRNA compared with uninfected cells. B) $24 \mathrm{~h}$ after infection cells were treated with $10-8 \mathrm{M} \mathrm{E}_{2}$ for 30, 60 and $90 \mathrm{~min}$. At 90 mins the amount of c-myc mRNA was significantly increased in cells infected with ERRßL compared to ERRßS (*, p<0.001 using a 2 way ANOVA).

Figure 3: Impact of ERRß splice variants on cell proliferation as determined by MTT assay.

Cell proliferation was assessed using the MTT assay $24 \mathrm{~h}$ after addition of DMSO or $10^{-9} \mathrm{M}$ E2. Over expression of ERRßL significantly increased proliferation compared that recorded in cells overexpressing ERRßS (data expressed as mean $\pm \mathrm{SEM}$; *, $\mathrm{p}<0.05$; Kruskal-Wallis test followed by a Dunn's Multiple Comparison Test).

Figure 4: Overexpression of ERRß variants does not alter of the amount of ER $\alpha$ or ERß mRNAs

15 Ishikawa cells were transfected with ERRßL or ERRßS plasmids, total RNA was recovered after $48 \mathrm{~h}$ and mRNAs determined by qRT-PCR. No significant difference was seen in the expression of ER $\alpha$ (A) and ERß (B) mRNAs compared with controls. The graph represents the average of 3 independent experiments and the data was expressed as mean \pm SEM.

Figure 5: FRAP analysis revealed a difference in the intra-nuclear mobility of ERRß variants.

Ishikawa or COS7 cells were transfected with YFP-tagged ERRß constructs and the rate of recovery between 3 to 30 seconds after photo-bleaching was determined. A. Fluorescent proteins were detected in the nuclear compartment; ERRßS showed a rapid $(<3 \mathrm{sec})$ recovery after bleaching whereas when using ERRßL the bleached area was still clearly visible 30 seconds after firing of the laser. These observations were similar whether the cells used were: $\mathrm{B}, \mathrm{COS} 7$ (ER negative, $* \mathrm{p}<0.05$ ) or $\mathrm{C}$, Ishikawa (ER $\alpha$ positive). In Ishikawa cells the rate of recovery of ERRßL was significantly reduced $(\mathrm{p}<0.0001$, *) compared to ERRßS but the addition of PPT had no impact on the mobility of either splice variant ERRß (hatched bars) and they remained significantly different from each other $(* *)$. The data is expressed as mean \pm SEM.

\section{Figure 6: FRET analysis suggests a ligand-induced physical interaction between}


Ishikawa cells were co-transfected with CFP-ER $\alpha$ plus YFP-ERRßS (open bars) or YFPERRßL (solid bars), FRET analyses were carried out with or without the addition of $10^{-8} \mathrm{M}$ PPT. A minimum of 20 cells were analysed in each treatment. Positive control cells were transfected with pCY24 whereas negative controls were co-transfected with two different

5 plasmids containing CFP or YFP alone. This experiment was performed 5 times. FRET efficiency was significantly $(\mathrm{p}<0.0001)$ increased in cells co-transfected with ER $\alpha$ and ERRßL treated with PPT compared to untreated $\left(^{*}\right)$. The results are expressed as mean \pm SEM 
A

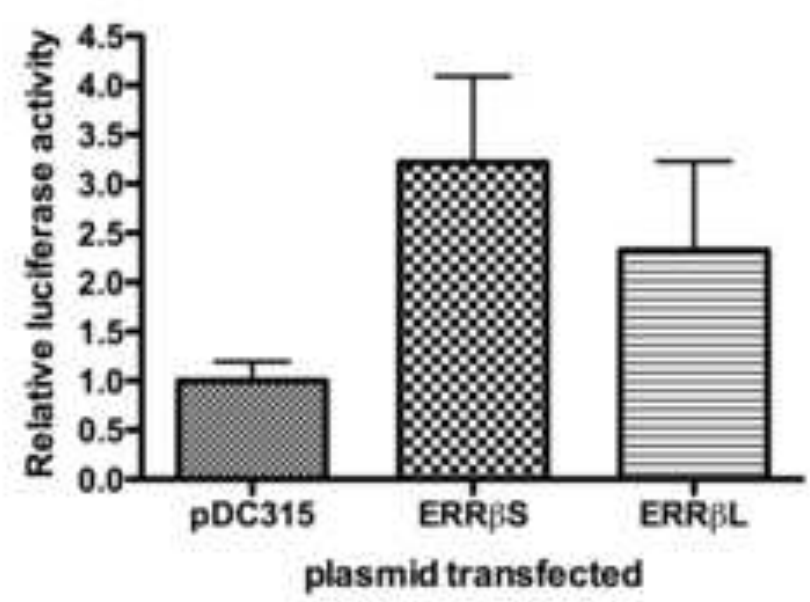

C

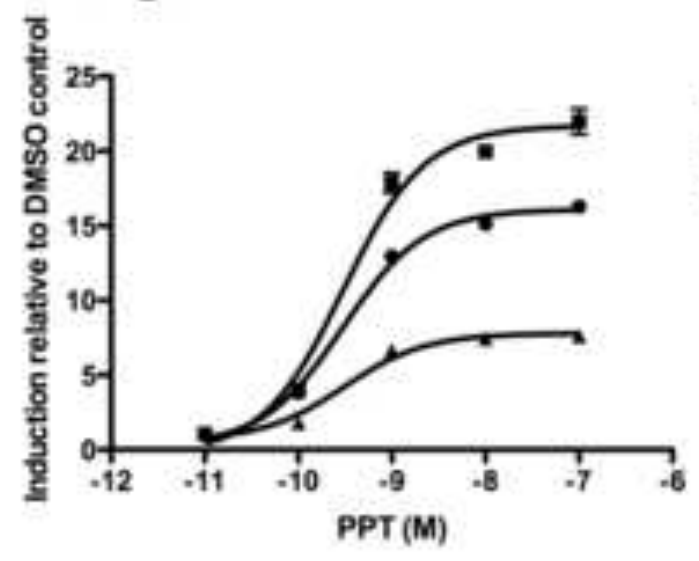

E

ERa

shER $\alpha$

neg sh

ShERB
B

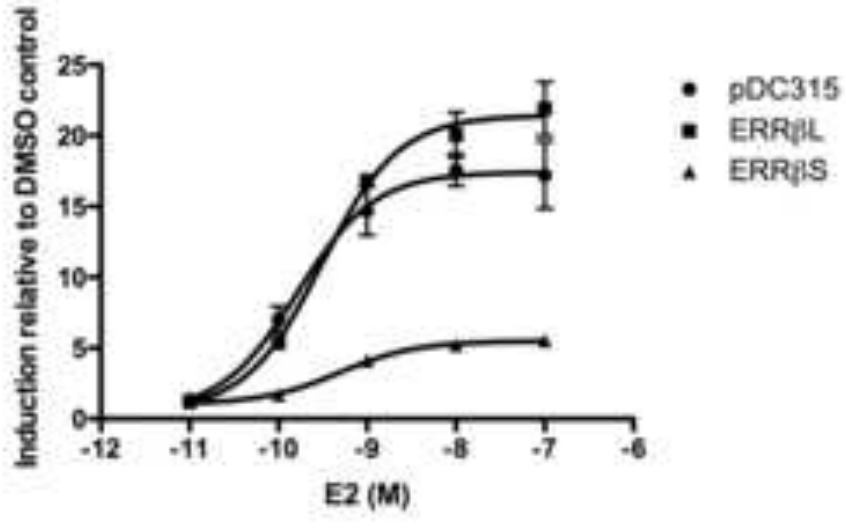

D
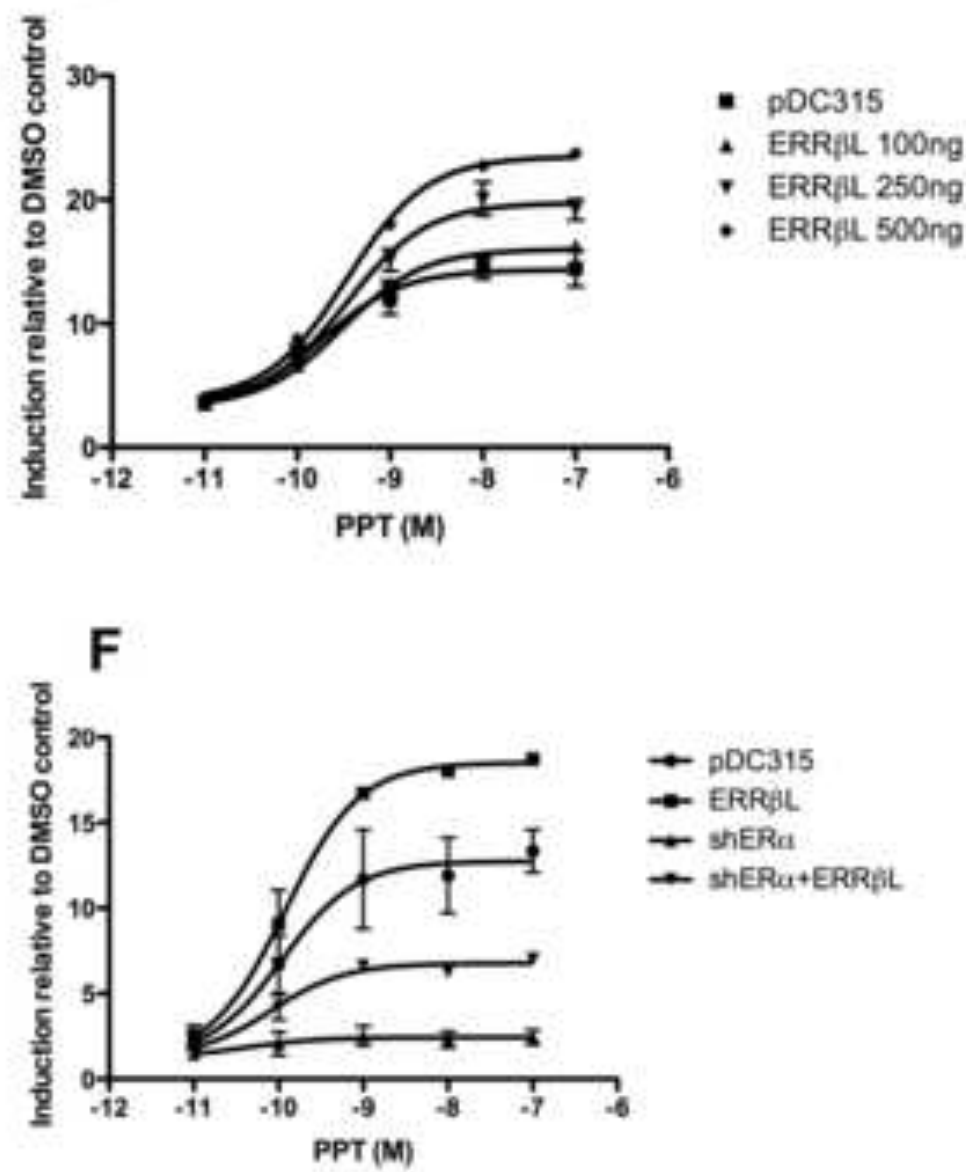
A

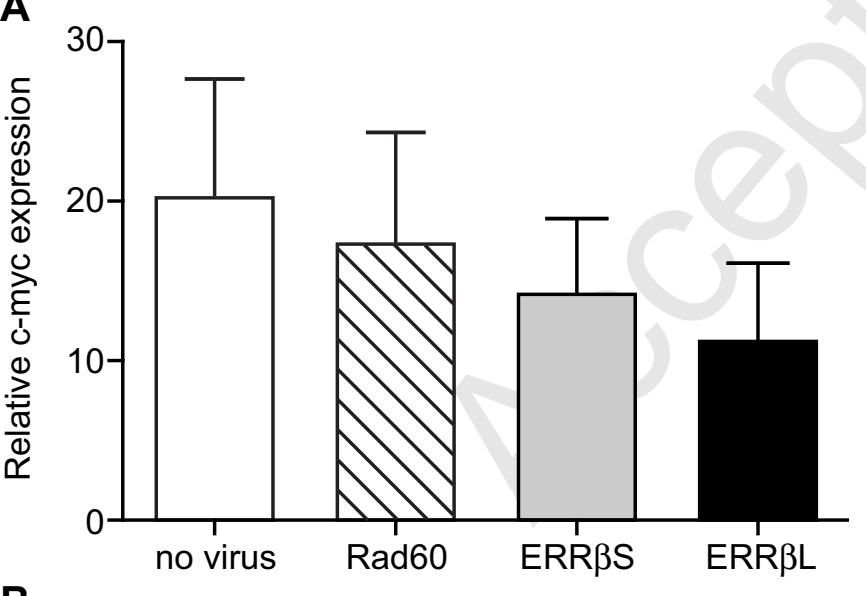

B

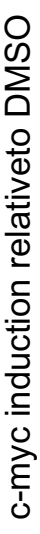
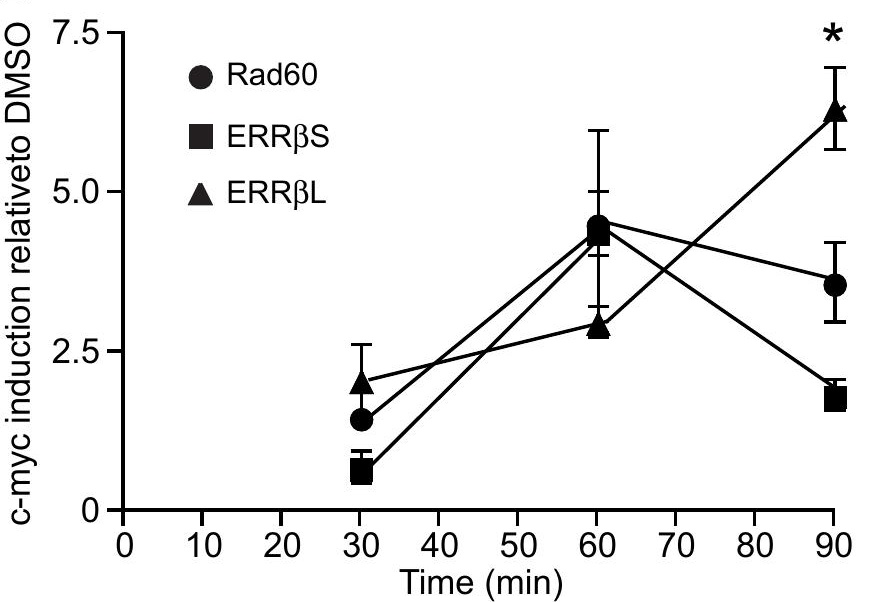


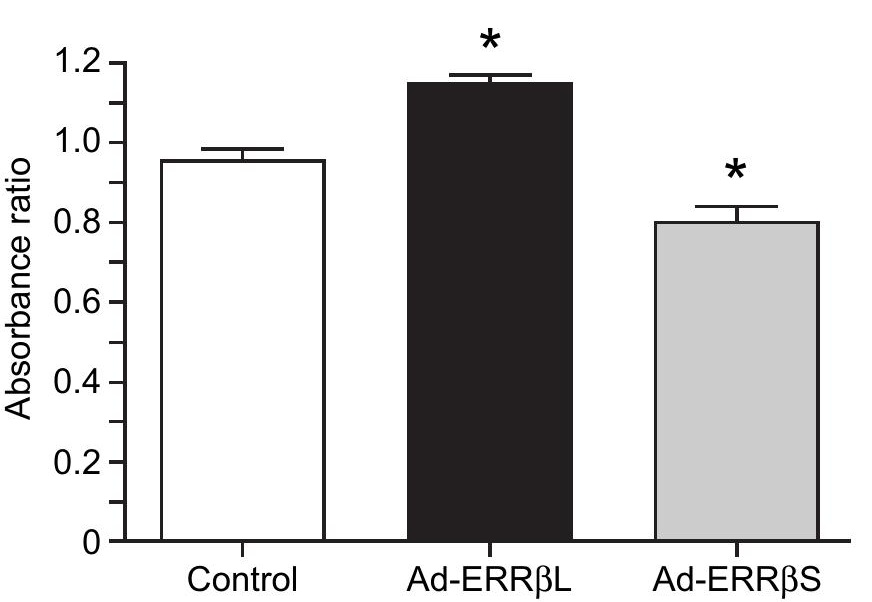

Figure 3

(2)

Page 25 of 28 


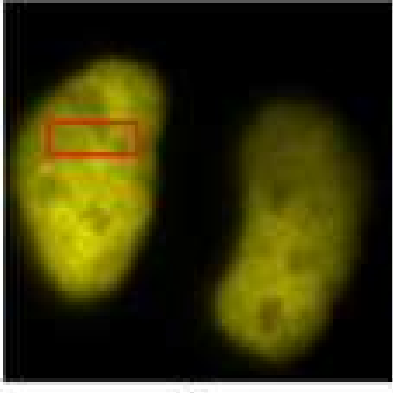

$+6 \mathrm{~s}$

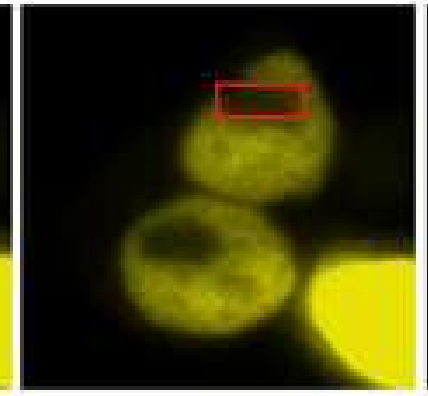

$+6 s$

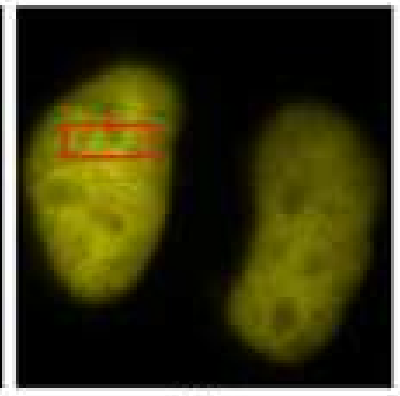

$+30 \mathrm{~s}$

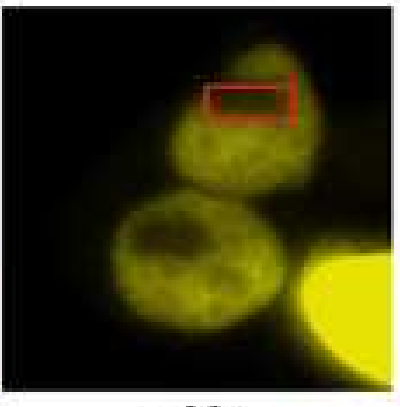

$+30 \mathrm{~s}$

\section{A ERR $\beta$ short
Before
ERR $\beta$ long
Before \\ A ERR $\beta$ shor
ERR $\beta$ long
Before
Before \\ A ERR $\beta$ shor
ERR $\beta$ long
Before
Before \\ A ERR $\beta$ shor
ERR $\beta$ long
Before
Before}

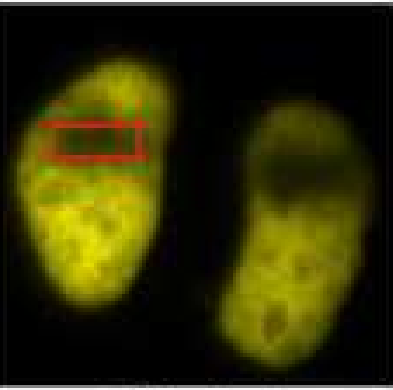

Bleached

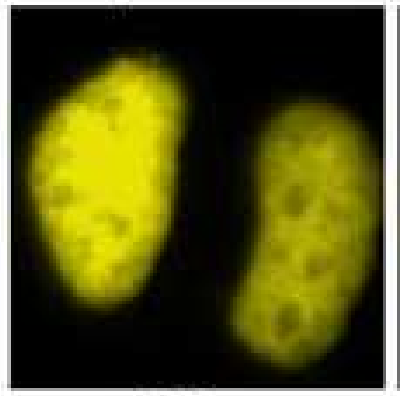

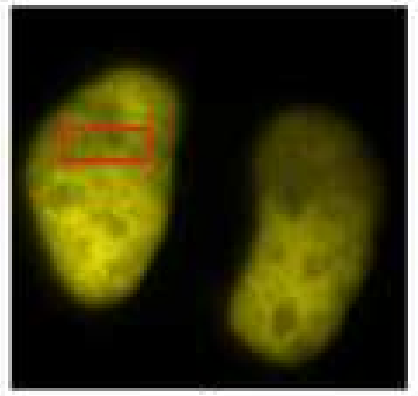

$+3 \mathrm{~s}$

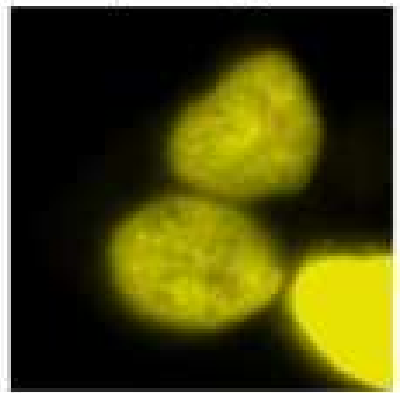

B

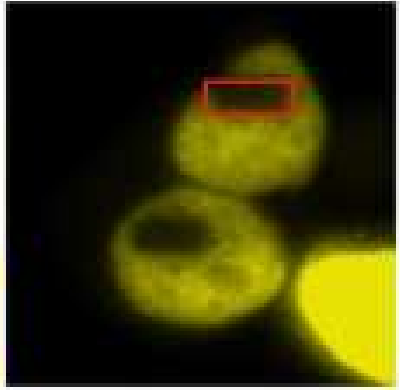

Bleached

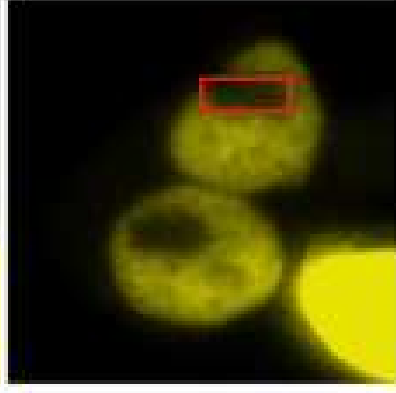

$+3 \mathrm{~s}$

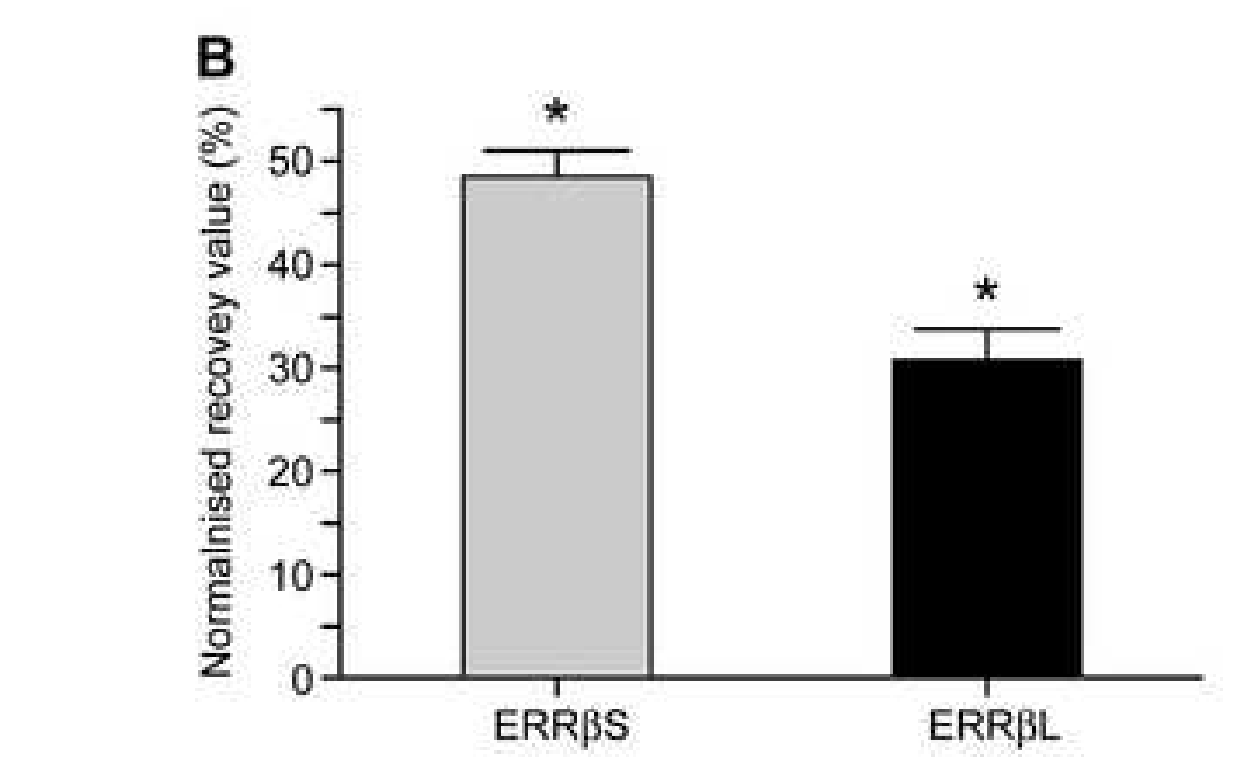

C

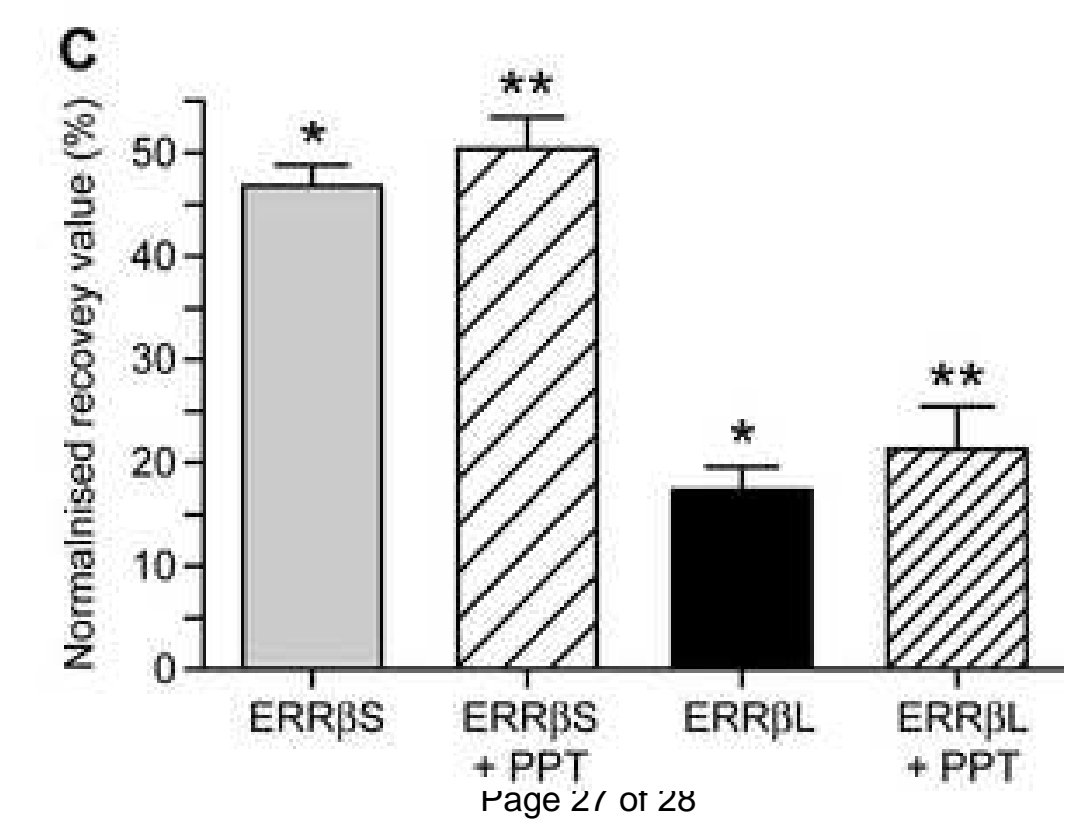




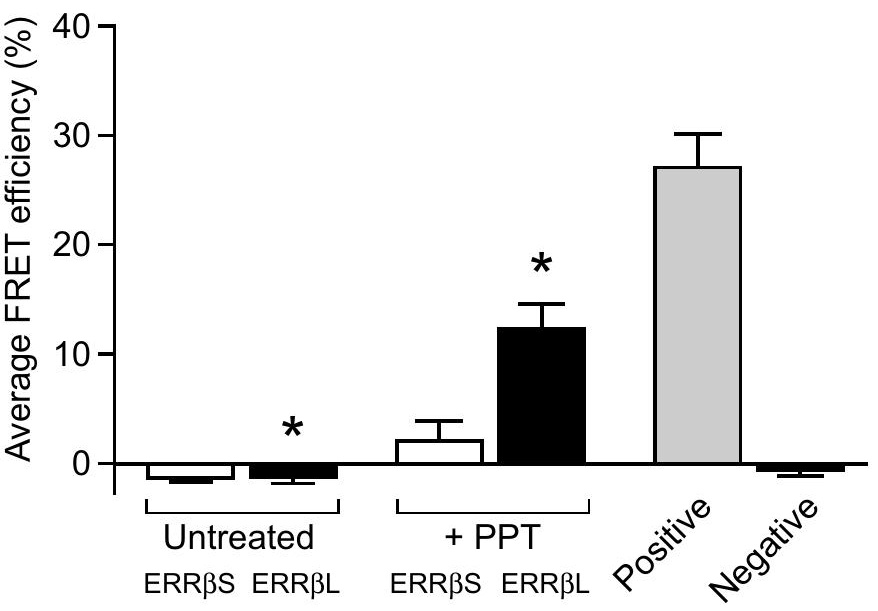

